\title{
STUDY OF THE PERIPHERAL BLOOD CIRCULATION IN ABDOMINAL WALL USING OPTO-ELECTRONIC PLETHYSMOGRAPH
}

\author{
${ }^{1}$ Katelyan O.V., ${ }^{1}$ Himych S.D., ${ }^{1}$ Kolesnic P.F., \\ ${ }^{2}$ Pavlov V.S., ${ }^{2}$ Kozlovska T.I., ${ }^{1}$ Barylo A.S. \\ ${ }^{1}$ Vinnytsia National Medical University (VNMU), named after M.I.Pirogov; \\ ${ }^{2}$ Vinnitsa National Technical University, \\ e-mail:psv@vntu.edu.ua
}

Introduction. The human health directly depends on the state of peripheral blood circulation. Blood filling disturbance causes various types of disorders of our body. For example it causes the bad healing of postoperative wounds. Therefore, for timely and qualitative diagnosis of such disorders the modern medicine uses non-invasive methods; these methods allows painless and non-destructive control of affected areas. The most perspective among them are optical methods for recording and transforming of biomedical information $[1,2,5]$. Obesity is one of the actual problems of modern world medicine, and it's one of the reasons of the bad healing of postoperative wounds. It is caused by the difference in the blood filling of tissues in patients with different body mass.

Method and results. An analysis of the blood filling of the anterior abdominal wall was provided on the basis of the VNMU Department of General Surgery and of the Surgical Department of the Clinical hospital №1 in the city of Vinnytsia. Determination of the blood filling was carried out by means of opto-electronic plethysmograph, which was developed by us.

Were examined patients with inguinal groin hernias (20 men and 20 women) with different body mass, aged $27-75$ years. All patients were divided by body mass index (BMI) and by the degree of obesity into 4 groups. The $1^{\text {st }}$ (control) group included 15 patients with normal body weight (BMI 18.5-24.9). The $2^{\text {nd }}$ group included 9 patients with overweight and the I degree of obese (BMI 25.0-29.9 and 30.0-34.9 respectively). The $3^{\text {rd }}$ group included 10 patients with II degree of obese (BMI was 35.0-39.9). The $4^{\text {th }}$ group included 6 patients with obesity of the III and IV degrees (BMI $\geq 40.0)$.

At that time, starting from the $2^{\text {nd }}$ day after surgery treatment was performed stimulation of microcirculation in the area of the postoperative wound for patients with obesity of the III and IV degrees. And was measured the blood filling in the tissues of the postoperative wound area before and after surgery. There were 32 patients (18 men and 14 women) aged 28 to 60 years old 
with obesity of the II degree (BMI 35.0-39.9) and 18 patients (5 men and 13 women) aged 35 to 58 years with obesity of the III and IV degrees (BMI $\geq 40.0)$.

Were calculated the mean value $M$ of microcirculation filling level, the mean square deviation $S$, the mean error, the mean value $m$, the probability criterion $t$, the probability value $P$. The differences between the comparable indicators were found to be reliable if the value of probability was greater or equal to $95 \%$ ( $P \leq 0.05)$. The dynamics of factors is shown in the table 1.

To compare the data obtained before and after the operation, the results of the study were presented in percentages. The start points before the operation were presented as $100 \%$ (Table 2).

Table 1

\section{Dynamics of the blood filling factor in the tissues of the anterior abdominal wall before and after surgery}

\begin{tabular}{|c|c|c|c|c|c|}
\hline \multirow{2}{*}{$\begin{array}{c}\text { Groups of } \\
\text { patients }\end{array}$} & \multicolumn{5}{|c|}{ The blood filling factor } \\
\cline { 2 - 6 } & Before & $\begin{array}{c}\text { The first } \\
\text { day after } \\
\text { surgery }\end{array}$ & $\begin{array}{c}\text { The third } \\
\text { day after } \\
\text { surgery }\end{array}$ & $\begin{array}{c}\text { The fifth } \\
\text { day after } \\
\text { surgery }\end{array}$ & $\begin{array}{c}\text { The } \\
\text { seventh } \\
\text { day after } \\
\text { surgery }\end{array}$ \\
\hline $1^{\text {st }}$ group & 1.16 & 1.26 & 1.06 & $1.62^{* *}$ & $1.69^{* *}$ \\
\hline $2^{\text {nd }}$ group & 1.04 & 1.17 & 1.05 & 1.08 & 1.31 \\
\hline $3^{\text {rd }}$ group & 0.94 & $1.18^{*}$ & $1.43^{* * *}$ & 0.79 & 0.82 \\
\hline $4^{\text {th }}$ group & 0.68 & $2.06^{* * *}$ & $0.34^{* * *}$ & 0.63 & 0.71 \\
\hline
\end{tabular}

Notes: ${ }^{*}-\mathrm{P}>0.05$ relatively to the $1^{\text {st }}$ group; ${ }^{* *}-\mathrm{P}>0.01$ relatively to the $1^{\text {st }}$ group; *** $-P>0.001$ relatively to the $1^{\text {st }}$ group.

Table 2

Dynamics of relative blood filling rates in the tissues of the anterior abdominal wall before and after surgery

\begin{tabular}{|c|c|c|c|c|c|}
\hline \multirow{2}{*}{$\begin{array}{c}\text { Groups of } \\
\text { patients }\end{array}$} & \multicolumn{5}{|c|}{ Relative blood filling rates, \% } \\
\cline { 2 - 6 } & surgery & $\begin{array}{c}\text { The first } \\
\text { day after } \\
\text { surgery }\end{array}$ & $\begin{array}{c}\text { The third } \\
\text { day after } \\
\text { surgery }\end{array}$ & $\begin{array}{c}\text { The fifth } \\
\text { day after } \\
\text { surgery }\end{array}$ & $\begin{array}{c}\text { The } \\
\text { seventh } \\
\text { day after } \\
\text { surgery }\end{array}$ \\
\hline $1^{\text {st }}$ group & 100 & 108 & 91.38 & $140^{* *}$ & $145^{* *}$ \\
\hline $2^{\text {nd }}$ group & 100 & 112,5 & 99.05 & 103.4 & 125 \\
\hline $3^{\text {rd }}$ group & 100 & $125^{*}$ & $152^{* * *}$ & 84 & 87 \\
\hline $4^{\text {th }}$ group & 100 & $303^{* * *}$ & $50^{* * *}$ & 92.65 & 104 \\
\hline
\end{tabular}

Notes: * $-\mathrm{P}>0.05$ relatively to the $1^{\text {st }}$ group; ${ }^{* *}-\mathrm{P}>0.01$ relatively to the $1^{\text {st }}$ group; *** $-P>0.001$ relatively to the $1^{\text {st }}$ group. 
All patients had the increasing of the blood filling to the postoperative wound area during the next day after surgery. It is due to the reactive phase of inflammation by the classification of M.I.Kuzin (1990). Patients of the control group on the first day after the operation had the increasing of the blood filling in the tissues of the postoperative wound area to $8 \%$, patients of $2^{\text {nd }}$ group - to $12.5 \%$ ( $P>0.05$ relatively to the control group), patients of $3^{\text {rd }}$ group - to $25 \%$ ( $P>0.05$ relatively to the control group), patients of $4^{\text {th }}$ group - to three times ( $P>0.001$ relatively to the control group).

Such a difference in the growth rate of blood filling in different groups of patients was as a result of vasodilatation associated with the release of histamine, which was excreted in the degradation of mast cells and expanded the clearance of arterioles, capillaries, venules, and also accelerated capillary blood filling. So, patients who had increased body weight, a direct proportional increasing of the blood filling in the areas of postoperative wounds was observed [1, 4].

Conclusions. On the base of the research we can confirm about effectiveness of using of optoelectronic plethysmograph for study of the microcirculation of the anterior abdominal wall. It allows with high reliability to diagnose possible deviations in the process of healing postoperative wounds. It is very important for surgery, because helps to stimulate microcirculation in a timely manner $[3,4,6]$.

\section{References}

1. Pavlov S.V., Kozlovska T.I., Vasilenko V.B. Opto-electronic devices for diagnosis of peripheral circulation with high reliability.- NTB, Vinnitsa (2014).

2. Pavlov S.V., Sander S.V., Kozlovska T.I., Kaminsky A.S., Wojcik W., Junisbekov M.Sh. Laser photoplethysmography in integrated evaluation of collateral circulation of lower extremities // Proceedings of SPIE, 8698, (2013), 869808, doi:10.1117/12.2019336.

3. Pavlov V.S., Bezsmertnyi Y.O., Zlepko S.M., Bezsmertna H.V. The photonic device for integrated evaluation of collateral circulation of lower extremities in patients with local hypertensive-ischemic pain syndrome // Proc. SPIE 10404, Infrared Sensors, Devices, and Applications VII, 1040409 (30 August 2017).

4. Zlepko S.M., Sander S.V., Kozlovska T.I., Pavlov V. Analysis of the vascular tone and character of the local blood flow to assess the viability of the body using the photoplethysmographic device // Przeglad Elektrotechniczny. - 2017. - R. 93 NR 5. - P. 92-95.

5. Kozlovska T.I., Sander S.V., Zlepko S.M. et al. Device to determine the level of peripheral blood circulation and saturation // Proc. SPIE 10031, Photonics Applications in Astronomy, Communications, Industry, and High-Energy Physics Experiments 2016, 100312Z (28 September 2016).

6. Sander S.V., Kozlovska T.I. et al. Laser photoplethysmography in integrated evaluation of collateral circulation of lower extremities // Proc. SPIE 9816, Optical Fibers and Their Applications 2015, 98161K (17 December 2015). 